\title{
THE FEMALE INTRUDER: WOMEN IN FIFTH-CENTURY DRAMA
}

\author{
MICHAEL SHAW
}

I T is exceedingly difficult to assess the position held by women in fifth-century Athens. ${ }^{1}$ When we examine their position in fourth-century law, we find them defined as near slaves, or as perpetual minors. In fifth-century history, at least as Thucydides saw it, there were no women. Yet women play a prominent part in Athenian literature and visual arts; they are not invisible, not helpless as, children, not creatures of the harem. ${ }^{2}$

These two bodies of evidence can be reconciled in several ways. We can conclude that drama reveals how the restrictions on women worked out in practice, that women were not forced to remain inside the role assigned them. This can be supported with what signs there are that women did not stay inside the house, that they did have an interest in politics, and so on. Or we can assume that drama is about the fantasy of Athenians, not about their lives, and that the explanation for the importance of women in drama is to be found more in the fantasies of the nursery than in actual life. A third course is to say that the women of the drama are drawn from epic models, and hence have nothing to do with the contemporary scene. ${ }^{3}$

Although these conclusions seem to contradict each other, none of them can be

1. I shall refer to the following books and articles by the author's name: W. Arrowsmith, "A Greek Theater of Ideas," Arion, II.3 (1963), 32-56; A. P. Burnett, "Medea and the Tragedy of Revenge," CP, LXVIII (1973), 1-24; J. K. Campbell, Honour, Family and Patronage (Oxford, 1964); H. D. F. Kitto, Greek Tragedy2 (London, 1950); W. K. Lacey, The Family in Classical Greece (London, 1968); D. L. Page (ed.), Medea (London, 1967); E. Schlesinger, “ $\mathrm{Zu}$ Euripides' Medea," Hermes, XCIV (1966), 26-53; P. Slater, The Glory of Hera (Boston, 1968).

2. A. W. Gomme forcefully presented this view in "The Position of Women in Athens in the Fifth and Fourth Centuries B.c.," Essays in Greek History and Literature (Oxford, 1937), pp. 89-115. Cf. too D. C. Richter, "Women rejected out of hand. Literature works on all three levels at once. An explanation of women's role in drama must account for literature's relationship with myth, with the psyche, and with contemporary life.

However, before attempting such an explanation, we should observe one salient feature of both strands of evidence: neither literature nor the social documents are about women's place in society. The social documents do not show us actual women; the drama does not show us an actual society.

That the drama does not show an actual society may be obvious; that the social documents do not show us actual women may be less so. For instance, let us consider the matter of ownership of property. If ownership means the ability to alienate, as Aristotle said, and if the ability to alienate means the ability to sign the deed, then there seems to be no question of any Athenian woman's owning property. ${ }^{4}$ However, if we say that ownership resides in the person who decides to alienate, we find that the law tells us nothing about who owns, for example, a wife's dowry property. The law is only interested in who appears to make the transaction. Thus the law defines the ideal roles of men and women, while it is silent concerning their actual

in Classical Athens," $C J$, LXVII (1971), 1-8. An interesting general study of Greek women, although it unfortunately steers clear of tragedy, is the article by M. B. Arthur, "Early Greece: The Origins of the Western Attitude towards Women," Arethusa, VI (1973), 7-58.

3. The first view is essentially that of Gomme (n. 2), followed by H. D. F. Kitto in The Greeks (Harmondsworth, 1951; repr. with corrections, 1958), pp. 219-36, and by Richter (n. 2). For the second view, see Slater, p. 297. Gomme, p. 93, raises the third view in order to dismiss it.

4. Aristotle Rhet. 1. 5. 1361a21-22. See G. E. M. de Ste Croix, "Some Observations on the Property Rights of Athenian Women," CR, LXX (1970), 273-78. 
roles. On the stage that is society, as on the dramatic stage, the characters are all wearing masks.

Literature is also interested in how women are supposed to act, but it also looks behind this mask. It examines the effect of the visible man and the invisible woman on each other and those cases where the roles are altered or reversed. Time after time, for example, a man in a Greek play tells a woman that she should be silent, or that she should speak briefly; yet the admonition is nearly always fruitless.

Consequently, when we compare the evidence presented about women by literature and by social documents, we must consider the nature of each set of evidence. The social documents say what women should do, but they say little of what women actually did. Literature tells us what women should do and what they actually do; but this is literature and not life.

Literature and the social documents, as we have seen, both describe what women should do, what we will call the "image of women." In both cases, the image of women described is essentially the same, although this similarity is obscured by the fact that women in drama are all doing

5. T. B. L. Webster discusses Euripides' plays about "bad women" in The Tragedies of Euripides (London, 1967), pp. 13-14, 31-101. I am stretching his use of the term, of course.

6. This can be seen from the tenacious survival of the oikos after the superstructure of society has been changed or destroyed. For the survival of the oikos of noble families in later antiquity, see P. MacKendrick, The Athenian Aristocracy: 399 to 31 B.C. (Cambridge, Mass., 1969). For the survival of the oikos in modern Greece, see Campbell.

7. It is this strong sense of privacy which leads to calling the house a "prison"; e.g., F. A. Wright, Feminism in Greek Literature (London, 1923), p. 58. However, the sight of a woman in public seems to shock the orators less than the sight of one man invading the house of another when women are inside (e.g., Dem. 47. 38, 53, 57). See Lacey, pp. 161-62. Prisons are mainly distinguished from fortresses by the attitude of their inhabitants.

8. C. A Savage, The Athenian Family (Baltimore, 1907), p. 28, quotes Plato's terse summary of a woman's duties as therapeia, tamieia, paidotrophia (Laws 806A). Demosthenes what women should not do. (Indeed, by the very act of being in a drama, which always occurs outside the house, they are doing what women should not do.) However, it is always clear in the drama that these are not foreign women acting normally but Athenian women acting abnormally, intruding into the male domain. They are all, to borrow T. B. L. Webster's phrase, "bad women." 5 In order to demonstrate this, we must first construct, in bare outline, the image of male and female as they appear in the social documents.

The image of both men and women is fundamentally determined by their relation to the oikos. As Xenophon said (Oec. 7. 30 ), the woman's place is in the home, the man's place is outside it. Here we should remember that the Greek oikos was a home in the fullest sense and more. It was a selfcontained universe, ${ }^{6}$ shut off from the outside world, ${ }^{7}$ whose primary functions were to produce the necessaries of life, care for its aged, raise the next generation, and care for its dead ancestors.

The wife's virtues are those demanded by the oikos, mother love, industry, and the ability to create harmony. ${ }^{8}$ There are certain negative virtues as well. She will not normally be known in public, because this implies that something is wrong inside the house which is driving her outside. 9

(59. 122) says that men have hetairas for pleasure, pallakas for day-to-day care of the body, wives to bear children and to be "a trusty guard of the things inside." See also Lacey (p. 176): "Athenian women as much as Athenian men were regarded as part of the city, so that they too were expected to subordinate their duty to themselves to their duty to the state and to the oikos to which at their marriage they would come, or had already come." For a parallel view of women's place and function, drawn from modern Greece, see Campbell, pp. 150-51.

9. This is, I take it, the meaning of Pericles' famous words in the Funeral Oration, "Greatest (glory) will be hers who is least talked of among the men whether for good or for bad." (Thuc. 2. 45; trans. Crawley). The woman in society is also a positive threat to her oikos. If a woman has engaged in adultery, it is impossible to be certain that the children are in fact the husband's children (Lys. 1. 33). And there were frequently relatives who would seize upon the slightest pretext to disqualify a man's children and take the property for themselves: e.g., the case being discussed in the two speeches 
She will be obedient since most decisions involve the outside world and are part of the man's preserve. If she is dominant, her husband will appear to lack decisiveness himself, and therefore she will harm his honor. ${ }^{10}$ Since his honor is in fact the standing of the house in the community, a woman's domination eventually harms the oikos itself.

These basic outlines of a woman's duty also explain her morality. In her world, the highest good is co-operation and harmony, not competition and strife. A woman's friends are all relatives ${ }^{\prime 11}$ her friendships can only be broken by death. The only contract she has participated in is a permanent one, her own marriage. ${ }^{12}$ Every person who is not a relative is a potential enemy.

Similarly, the image of man is determined by the fact that his sphere lies outside the house. His basic duty is to defend the oikos in the outside world. He does this by means of associations with other men, the heads of other households, the largest association being the polis itself. In these associations he gains protection and advancement in return for giving it to others. Similarly, in trade the man is representing his oikos in the wider economic community. ${ }^{13}$

Since the success of a man's actions is

of Hypereides defending Lycophron, found in J. O. Burtt (ed.), Minor Attic Orators, II (London, 1954), 370 ff. Lacey (p. 159) stresses the importance of legitimacy as a cause for the seclusion of young women.

10. The converse of this has been clearly stated by W. A. Becker, in Charicles-Private Life of the Greeks, trans. Frederick Metcalf(London, 1845), p. 340: "Except in her own circle, a woman's life was scarcely noticed; and though now and then an extraordinary instance of female sophrosyne, e.g. Phocion's wife, was publicly recognized ... the homage was clearly intended mainly for the husband." A similar attitude is described in a modern Greek culture: "It is important for a man's self-regard (egoismos) that other men should see that he is master in his own house. In public the wife is meek and modest, silent and submissive" (Campbell, p. 152).

11. Support for the idea that the woman's moral universe was the older, tribal world can be inferred from the fact that the one role we can see women playing in fourth-century trial courts is'swearing oaths (Isae. 12.9; Dem. 29. 26; 39; 40). See measured by the honor the community gives him, honor is his highest goal. Friendship in the male world, then, is in the final analysis secondary to advantage. 14 Indeed, nothing is higher than advantage. There is no crime in the man's world except acting to his own disadvantage.

Here a question might be raised: What of the cases where honor and advantage are in conflict? The answer is that by "advantage" I mean both "honor" and "profit." Indeed, the Greeks used the same word, time, to describe them both. The man who seeks honor and the man who seeks profit are vastly different men, but they are both men.

Obviously, a person who conforms totally to either the male or the female image is only half a person. A society which ignores the female is sterile and lacks emotional foundations. One that ignores the male is plunged into interfamilial feuding. The male and the female are exclusive and hostile; yet, since Greek civilization is a unity of oikos and polis, the two principles must be kept in balance.

The image of women is much the same in Homer and in Greek drama, but there is a striking difference in the way that image is presented. This can be seen if we compare

Lacey, pp. 174, 312, n. 145. A. R. W. Harrison, The Law of Athens: The Family and Property (London, 1968), p. 79, aptly criticizes Lacey: women's ability to swear oaths should be separated from the ability to give evidence. No doubt the earliest court proceedings were no more than oaths taken by accused and defendant, the procedure which the Furies suggest Orestes should follow (Aesch. Eum. 429).

12. See Lacey, p. 156.

13. It is precisely this social sense which seems atrophied in modern Greece. J. K. Campbell and P. Sherrard, Modern Greece (London, 1968), p. 355, point out that agricultural co-operatives have had limited success because the farmer always acts for the immediate benefit of his family and never for the good of the co-operative itself. They find the same phenomenon in the business sphere, where they cite figures which show that most businesses are family owned (p. 372).

14. Ajax observes this feature of political life with disgust: "Most men consider friendship a faithless harbor" (Ajax 682-83). Odysseus simply accepts it (Ajax 1359). 
the scene between Andromache and Hector at Iliad 6. 404-93 with Sophocles' adaptation of that scene, the confrontation of Ajax and Tecmessa at Ajax 430-524.

Andromache reflects the qualities of the ideal woman, in her fear for Hector, in her dependence on him, and, finally, in her obedience to him. However, she is not purely female: in nearly half her lines she speaks of her father and his honor and of her mother the queen, and she ends her speech with a piece of strategic advice.

The matter of Hector's speech is also essentially male, in that he rejects Andromache's fears because of the necessities of honor. But although he rejects the feminine for the sake of the masculine, Hector has many feminine qualities: pity, love, and even being able to contemplate withdrawing from society.

In the parallel scene from the Ajax, we find, in Ajax' first speech (430-80), that Ajax has no thought of anything but honor. In Tecmessa's reply (485-524) she barely mentions her own family, her own honor (487-88). Tecmessa also says that if Ajax dies he will leave her in the hands of his enemies, which will be a reproach to Ajax and to his family (492-505). We should note that this is taken from Hector's speech in Homer.

In each of these instances, we can see that Sophocles is altering his Homeric models, so as to produce in Ajax and Tecmessa characters which are purely male and purely female. However, as the play progresses, Ajax gradually reveals feminine qualities, and Tecmessa eventually speaks like a man. Ajax speaks of his love for Eurysaces (552-59), and then of his pity

15. This is described by Kitto (p. 204), but as a Euripidean feature: "The greatest difference between Euripides' and Sophocles' approach to tragedy is that Sophocles concentrates into one hero what Euripides splits up, prismatically, among a group." Arrowsmith (pp. 40-41) seeks to explain this: "The wholeness of the old hero is now represented divisively, diffused over several characters; the paired antagonists of the Euripidean stage thus represent the warring modes of a divided for Tecmessa (652-53); Tecmessa boasts of Ajax' honor (961-65).

This difference between Homer's treatment and that of Sophocles is mainly due to a change in the way they use images. Sophocles first presents characters who are purely male and female. ${ }^{15}$ Then the female invades the male; finally, both characters have the duality which was present from the beginning in the scene between Hector and Andromache. What Homer has done simultaneously, Sophocles does consecutively.

A similar progression occurs in Euripides' Medea. The pure female meets the pure male, and there is an impasse. Next, the female intrudes into the male domain, and the male image is reformed. Admittedly, there are great differences between the Ajax and the Medea, but the pattern is the same.

The first question we must face is whether we are to think of Medea as a Greek woman at all. After all, she is a barbarian, and it would be easy to explain away her actions on this ground. This is, in fact, the course taken by Jason: "There is no Greek woman who would ever have dared this" (1339-40). ${ }^{16}$ Indeed, there is some truth to what he says, but is it the whole truth? Is she as foreign as an interplanetary visitor, or is she a true monster, something which belongs to a recognizable group but which somehow violates the norms of that group?

Let us consider to what degree Medea corresponds to the "image of woman." The central question here is: Is her world

culture and the new incompleteness of the human psyche. Alternately, as in the Bacchae, they embody the principles of conflicting ideas; Pentheus as nomos, Dionysus as physis." These comments also apply to the great pairs of Sophoclean drama-Antigone and Creon, Ajax and Tecmessa, Heracles and Deianeira, perhaps even Philoctetes and Odysseus-and to the great antitheses of the Oresteia.

16. The translations of the Medea are my own. 
primarily the home? The nurse answers in her opening speech:

She endures all with Jason.

This is the greatest salvation:

When the woman sticks with the man

[13-15].

Furthermore, Medea has no world other than Jason's world. In order to support him, she has betrayed her family and killed the king of Iolkos (483-86). There are horrors in Medea's past, but she has been true to Jason. To look to her husband's will, and to his will alone, is the basic fact of a woman's life, as Medea herself says (247). Medea's actions have been exceptional in degree, but in nature they have been typically feminine, typically Greek. ${ }^{17}$

Her moral values are also typical of a Greek woman. Inside the house the bonds between friends are permanent, and they are of blood. In the case of man and wife these bonds are children, and Medea tells Jason she could forgive him if he were still childless (490-91). ${ }^{18}$ In terms of the archaic values of the oikos, Jason's disregard of his oath to her is simply absurd:

Oaths can no longer be believed. I cannot understand it;

either you believe the gods you swore by no

longer exist,

or that the laws now governing men are new, since you know as well as I that you've broken your oath [492-95].

On the other hand, Medea differs from the average woman in her ability to affect the world outside the house. The way in which Medea affects the outside world, however, is basically feminine. Her skills differ from the skills of a Greek woman

17. Schlesinger (p. 44) points out that Medea's situation, as she describes it here, symbolizes the fate of women in general, and that the origin of this type is the Andromache of Iliad 6. I would add another example of this type, the strikingly similar speech preserved in Soph. Frag. 583 (Pearson), which Is from the Tereus.

18. Despite the forms of society, it is children that make a marriage in Greek eyes. Euphiletus watches his wife with great care when they are first married, but trusts her com- only in degree. First, Medea's daring is a typically feminine quality, as she explains: "When a woman's bed is wronged, / no mind is more murderous-foul" (265-66). Jason himself admits this is a basically female trait (569-73). She also knows how to lie, a skill she displays when she meets Creon, and later in her scenes with Aegeus and with Jason. One could hardly call this an uncivilized skill!19 Medea's most striking skill is her knowledge of medicines; she says it is the way in which she is most wise (384-85). Is this skill foreign to a Greek woman? The god who helps Medea with her medicines is a Greek god, Hekate, and this god lives in a typically feminine place, the hearth (397). There is abundant testimony to the Greek woman's use of potions, which I will pass over (e.g., Antiphon 1).

The medicines themselves are not prominent in the play, but the effect of them is very prominent. Who could ever forget the account of the young princess' death? What is this fire that disfigures and destroys her, and then destroys her father?

First we might note that this is not the first time in this play that a daughter has destroyed a father. Medea persuaded the daughters of Pelias to kill their father (9-10; 486-87); Medea herself betrayed her father and house because of her love for Jason (483-85). Indeed, Medea never kills the head of a household in this play; each time she destroys the head of the house through his children: Pelias through his daughters, Creon through his daughter, Jason through his children. At the end of the play, we discover how Medea betrayed

pletely after the birth of their first child (Lys. 1). This attitude can still be seen in modern Greece: Campbell (p. 87) notes that a new bride is not accepted by her husband's relatives until the birth of her first child. See also Lacey, pp. 15, 70 .

19. Page (p. xix) considers her "childish surprise at falsehoods and broken promises" a barbarian trait, which implies that Medea's lying and deceit are civilized. However, this trust in oaths (see n. 12) and the skill at lying both seem to me to be more Greek, and more feminine, than barbarian. 
her father and house: she killed her father's son, her own brother (1334). There is also a positive side to this power, which we see when Medea offers to use her medicines to get children for Aegeus (718).

Medea's poison, then, is not magic but a symbol. It represents the ability to create, destroy, or pervert the bonds between father and child. It is love, and its god lives in the hearth. It is fire, and its user is descended from the sun.

In opposition to Medea stands Jason. Jason, like Ajax, is purely male. There is a vast difference between them, of course. Jason defines honor as money, which is gained by any means and whose primary virtue is its use; Ajax defines honor as the arms of Achilles, whose primary significance is not how they can be used, but how they are gained. However, granted this difference, and it is a large one, Jason and Ajax are both males, obsessed with their role in society, with honor.

Thus, where Ajax speaks only of honor, Jason speaks only of profit, of money. He grants that Medea has profited him (533), and he claims that profit, not love, is his motive for deserting Medea and marrying the princess (559-65). However, when Jason reveals how he intends to use the money and friends he will gain, we see how typically male his goals are. He wants to raise his children as befits his house, and he wants to join his house with the house of Creon. That is, he wants to secure the status of his house in society.

Because of his obsession with society's rewards, Jason has no respect for the means used to gain them. He refuses to admit a debt to Medea; it was Aphrodite, not Medea, who saved him (527-28). But

20. Whether or not Jason is a character of importance is a major question in the criticism of the Medea. Kitto sees him as merely the trigger for Medea's emotional fireworks, "a ready-made villain" (p. 206). Jason is singularly repellent. However, his plan to marry a citizen would seem reasonable to an Athenian, as A. W. Verrall pointed out in his edition of the Medea (London, 1881), p. xix. R. B. Palmer, "An Apology
Jason also despises the goddess who saved him:

You women have come to such a state that you think you have everything if your love life is in order.

If something happens to your bed you consider the best and most beautiful to be hostile. Men should make children somewhere else, and abolish women

[569-74].

Jason's own motives for marrying the princess have nothing to do with Aphrodite (555-56). Jason's attitude toward Aphrodite closely resembles that of Hippolytus. They both would be rid of women (Hipp. 618 ff.), but Jason, unlike Hippolytus, has used Aphrodite's power when it was convenient.

In terms of the male image we have delineated, we could call Jason "pure male." He only wants to secure the place of his house in society, and the fact that his actions violate the laws within the house is a minor hindrance, an irritation. He would get rid of this irritation with a typical male remedy, buying Medea off (610-13). Before passing hasty judgment, one should ask, does our society offer anything substantially different to the minority groups, to the aged, to women? Jason is simply thinking like a politician, like a man. ${ }^{20}$

Jason's completely society-oriented values have a logical climax. He thinks that the greatest good Greece offers Medea is fame (539-44). Jason ignores the fact that fame means nothing to a woman. That is, Jason speaks to Medea as if she were a man with a man's values.

Jason is not evil; like Medea, he is looking for the good. They are both

for Jason: A Study of Euripides' Medea," CJ, LIII (1957), 49-55, developed this observation by illustrating the reasonableness of Jason's plan in the light of Attic law: only by marrying a citizen can Jason, and his oikos, become part of the polis. Thus Jason's claim that he is trying to help his family is real. We may not like Jason, but we cannot dismiss him out of hand as merely evil. 
isolated from any homeland. In Greek culture, where the city-state is like an extended family, where the only justice is each city's justice, this isolation is the closest thing to hell on earth. Medea looks to Jason, but Jason is alone. Being of no city, he is every man's enemy. Alliance to Corinth's rulers means that he will again have a place in a society. And this means that his house will be secure. He is thinking of his family's good, and this includes Medea. That he has a one-sided picture of what makes up his family's good is all too visible. But has he much choice?

We cheapen this play if we fail to admit one central fact: neither Jason nor Medea can solve the situation they are in. The only possible solution is for some Greek state to come forward and say, "Jason, we offer you the security of citizenship and kinship with our leading families, and you do not have to marry anyone." That is, the situation itself creates the tragedy. ${ }^{21}$ Jason must, in this situation, consider the advantageous and ignore his obligations to Medea; Medea must strike back.

In the first scene between Jason and Medea, man, the rational social animal, faces woman, the passionate, familial animal. Never does one sympathize with the other; this is a complete impasse. Jason addresses Medea in terms of reason

\footnotetext{
21. One of the important themes of this play is cultural isolation. Although Jason describes the benefits of being Greek (536-44) and the chorus speaks of the ideal Athens (824-45), Greek society is conspicuously absent from the actual situation of the play. Both Jason and Medea are cut off from all kin, and there is no law. Burnett (p. 18) points out the significance of the fact that the oikos represented on stage is not the palace but Medea's house, and that all of the characters except Creon are transients. Also, the chorus speaks as women, not as Corinthians (Schlesinger, p. 45). G. M. A. Grube, The Drama of Euripides (London, 1961), p. 105 , finds the bond of common motherhood hardly strong enough to induce them to connive at the murder of their princess and their king, but Arrowsmith (p. 49) points out that culture is "out of joint" in Corinth, and that this makes the chorus resentful of authority and sympathetic with rebels. Indeed, Creon never speaks as king of Corinth, only as an individual with exceptional power; one can say, then, that society does not exist in Corinth. The society Jason wants to join is seen by both Jason and Medea simply as wealth.
}

and social values; Medea answers in terms of passion and familial values. The male argument of advantage collides with the female argument of justice.

For instance, in lines 586-87 Medea charges that Jason is base because he has not told her; Jason replies in lines 588-90 that he was right to remain silent because argument would not have worked. There in no communication between them. Indeed, there can be none; they argue from different premises.

When there is complete impasse between male and female, as we saw both in Homer and in the Ajax, the woman usually simply yields and suffers. In the best of situations an Andromache has some comfort. She knows that her husband respects her situation, and she understands his situation. But Jason completely despises Medea's values, and she has no sympathy for his. Worst of all, she has no home to which she might go and weep. Jason has destroyed it.

Although her earlier actions were potentially male, and they have indeed won her fame, in actuality Medea has acted as a woman, since she acted for Jason's sake. However, vengeance on Jason is for her own sake. When Medea begins to avenge herself on Jason, she becomes a man. This change in Medea from female to male can be seen in the language she uses. Each time

Behind this stands the ideal Athens, the place to which Medea will escape, and to which we, too, escape, fleeing the social decay of Corinth (Burnett, p. 24). Athens has the balance of eros and sophia which in Jason and Medea have become antagonistic and destructive (H. Musurillo, "Euripides' Medea: A Reconsideration," AJP, CXXXVII [1966], 60 ; Grube, op. cit., p. 158). There we find aidos, reverence for oaths (Burnett, p. 23).

How do we respond to this contrast of Corinth and Athens? H. Erbse, "Uber die Aigeusszene der euripideischen Medea," WS, LXXIX (1966), 132, finds the tension between Euripides' realistic Medea and the mythical Athens too great. We cannot believe that the mythical Athens could have accepted such a woman, he claims, and so we conclude that the mythical Athens did not exist, and that the mythical Athens is not relevant to contemporary concerns. D. J. Conacher, Euripidean Drama: Myth, Theme and Structure (Toronto, 1967), p. 193, also speaks of their "hideous uncongeniality." I would suggest, as do several other critics, that Athens represents the cultural integrity missing in Corinth. 
she performs an act which is directed toward vengeance on Jason, she speaks as a male would normally speak: she refers to her grandfather and her father (her original family) and to her honor. Her frequently mentioned fear, that her enemies will laugh at her, is a part of her interest in her honor. ${ }^{22}$ This language first appears after the scene with Creon, where she had won her first victory:

Advance into terror. Now is the trial of courage. You see your sufferings. You must not be

mocked

by this marriage of Jason with the scoundrel

Corinthians.

You are descended from a noble father and from

the sun.

You know how

[403-407].23

What is monstrous is that this masculine concern with honor is based on feminine skills:

Furthermore, we are women, helpless in good, but of all evils the cleverest of technicians

[407-409].

After Medea wins a place of refuge from Aegeus, her second victory, she again speaks as a man: "Now we will have beautiful victory / over my enemies, friends" (765-66). "Beautiful victors" (kallinikoi) is an athletic term, a male term. ${ }^{24}$

22. That the fear of being a laughingstock is a noble fear needs some support, since Musurillo, op. cit., p. 72, has seen "no will to dominate here ..." and Grube, op. cit., p. 158, has referred to "her fear of being a laughing-stock-the fear of the weak and the outcast ..." It is the fate, not the fear, of the weak and the outcast to be laughingstocks. A striking example of this is Ajax' vivid realization that his madness has made him laughable (Ajax 367). Like Medea, Ajax sees his enemies laughing (382). This laughter has not been stilled in Greece yet: "The laughter of other people is invited in all situations where a man, or a group, has failed. 'The world laughs' ... at a man when he fails to defend his honour; for instance, when he does not reply to an affront" (Campbell, p. 313).

23. Medea's similar words in 395-98 were parodied by Eupolis (quoted by Page adiloc.):

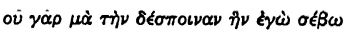

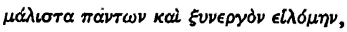

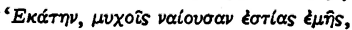

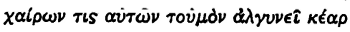

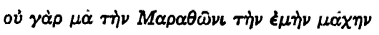

[Medea 395-98].

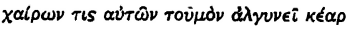

[Eupolis Demoi Frag. 90K].
The nurse has already used this word of Medea in the prologue (44-45).

The male part of Medea wants a "beautiful victory" over Jason, but complete victory requires the murder of his sons. Yet Medea is not purely male, and the female Medea, the mother of those sons, rebels as soon as this part of the plan is broached, after the exit of Aegeus: "I groan for the deed I must do / after that" (791-92). The male Medea answers that they must be killed, so that Jason's house will be destroyed (794), ${ }^{25}$ and so that her enemies will not laugh at her (797). She ends this speech with a resounding statement of the male credo: 26

Let no one think me worthless and weak or peaceful, but of the other sort, hard on my enemies, mild with my friends. The life of such men is the most famous [807-10].

Medea has taken Jason's challenge and become a man, and now she is as interested in fame as he is. But the price is high, the extinction of the woman within her. ${ }^{27}$ In her second scene with Jason, she manipulates him with her usual ease, but her involuntary outbursts of grief reveal that a part of herself is suffering and dying. She is killing Jason's wife as well as his children. At the same time her pretense allows

This shows the ease with which Medea's language can be put into the mouth of a Marathonomachos. Schlesinger's comparison (p. 53) of Medea and Achilles points in the same direction.

24. See Page ad 45.

25. Medea's murder of Jason's children is the perfect revenge, the ultimate expression of the code, "harm your enemies..." When Burnett speaks (p. 10) of "the true vengeance act, the killing of Jason," I would suggest that "normal" is a better word than "true." Slater asks why Medea was spared but Clytemnestra murdered, and concludes that the marriage bond was the weakest link in the Greek family (p. 164). It seems more reasonable to answer that Clytemnestra died because she failed to kill Orestes. Since killing children is an ultimate revenge, it is reserved for gods to perform with immunity, as, e.g., Apollo and Artemis kill the children of Niobe.

26. Compare the tone of these lines with Ajax 473-80.

27. Burnett (p. 21) draws an interesting and telling comparison: "In her own terms Medea's total conquest demands of her the same painful sacrifice that Agamemnon had to make to conquer Troy." Agamemnon had not borne Iphigenia, of course. 
Jason to reveal a more attractive side: he loves his children; and his plans, which we have found so despicable, were in fact made for them, as he had claimed in his first scene with Medea. ${ }^{28}$ This love for his children is Jason's female aspect, the part of him that Medea will destroy.

This war of male and female within the heart of Medea continues in her next scene, when she bids farewell to her children. The female Medea decides not to kill them (1044-48), but the male Medea says again she must not be laughed at (1049-52). Then the female Medea pleads, "No, spirit, do not do it!" (1056), but the male Medea finally overrides her (1059-61). The female has lost, and Medea is aware that she is letting her male heart (thymos) ${ }^{29}$ rule her plans (1078-80). Then, after the messenger tells of the death of Creon and his daughter, the die is cast. Her male side, with compassion, commands her female side to endure:

Forget for one short day your children, and then mourn. For even if you kill them, they were dear. I am an unfortunate woman

[1248-50].

28. We are too harsh with Jason if we dismiss his feelings for his children because he sees them simply in terms of social status (J. R. Dunkle, "The Aegeus Episode and the Theme of Euripides' Medea," TAPA, C [1969], 103; L. M. Mead, “A Study in the Medea," $G$ and $R$, XII [1943], 18; Schlesinger, p. 45). This is simply the way his own position in society forces him, and all men, to look at things. Significantly, he sees the children in a different light at the end of the play, when he longs to kiss them (1399-1400).

29. I agree with Burnett's definition of these words (p. 22): "The dialogue is held between a part of herself called thumos $(1056,1079)$, or sometimes kardia $(1042,1242)$, and another part that is meter (1038; cf. 1247 , etc.). Psychologically speaking it is a struggle between Medea's masculine, honororiented self and her feminine, hearth-oriented self." This does not contradict H. Diller's argument, in " $\theta v \mu \delta \dot{s} \delta \dot{\epsilon} \kappa \rho \in l \sigma \sigma \omega \nu$

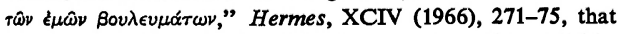
thumos means "passion" and bouleumata means "plans." The struggle within Medea is not simply reason versus passion (pace Conacher, op. cit., p. 196) but anger versus love (Mead, op. cit., p. 19), and both passions have their rationale. (Nor is the conflict between Jason and Medea one of reason versus passion. As Arrowsmith points out [p. 48], Jason's cool selfinterest and the "magical and erotic skills of the sorceress Medea" are both sophia.) Schlesinger declares (p. 30) that what opposes Medea's thumos is not another aspect of her will, but simply ordinary human feelings rebelling against her
Medea has left the position of a woman in Jason's house to take a position as a man in her father's house. The head of that house is her grandfather Helios, the sun. Will he accept this savagery? The question is raised three times at the end of the play. First the chorus prays to Helios (1251-60), asking him to intervene. Helios does intervene, but not in the way the chorus expected. For, when Medea next appears, she is in his chariot and under his protection (1320-22). Jason cannot comprehend this. He believes Medea is hated by the gods, and by the sun in particular (132328), despite the evidence before his eyes. A horrible deed it is, but Medea has her gods; not the social gods of Olympus, but the elemental gods of sun and earth. ${ }^{30}$

Now we see, I believe, in what sense Medea is a barbarian. She has subordinated her feminine skills to a purely masculine desire to dominate. ${ }^{31}$ But it is only now, with the horrible murder accomplished, that Medea has become fully barbarian. ${ }^{32}$ She has gradually lost her Greek character in the course of the play. Now she sits in the chariot of Grand-

fortune, which is forcing her to do a superhuman, heroic deed; but this still leaves us with two entities in Medea's nature that are warring with each other.

30. ". . . it is the visible cosmic force which blazes through Medea's motives, which her whole pathos expresses: the blinding force of life itself, stripped of any mediating morality or humanizing screen; naked, unimpeded, elemental eros; the primitive, pre-moral, pre-cultural condition of man and the world" (Arrowsmith, p. 50). See also Kitto, p. 208. However, this does not exhaust the sun's symbolism. He is Medea's grandfather, and he represents the blazing power behind all heroic action. Thus, when we see the chariot, we think of the power of physis; but we also think of the family Medea now rejoins as a man, and of the heroic victory-in-destruction which she has achieved.

31. Arrowsmith (p. 49) considers Medea's main barbarian characteristic to be that her physis is but imperfectly governed by nomos, so that she can be quickly reduced to her "essential physis." Medea's physis is certainly of unusual power, but it is always subject to a nomos. When she sheds the Greek nomos, she returns to the barbarian nomos. One of the most prominent aspects of the Greek concept of barbarians is that their women acted like men (e.g., Artemisia).

32. "Fully" is too extreme; Medea is not totally free of her feminine side in the exodos. This is what makes this scene nastier, more personal, than the exodos of the Bacchae. 
father Sun, which is essentially where she was when Jason found her. And it is Jason who forced her to return.

One final aspect of the image of male and female remains to be seen. When Medea has finally reached and broken Jason in the last scene, this rational and practical man is forced to use the old moral vocabulary, the language of the family and tribe: "unholy murder" (1305), "most irreverent deed" (1328), "betrayer" (1332), "curse" (1333), "shameful doer and foul murderer of children" (1346), "pollution" (1371), "Fury . . . Justice" (1389), "polluted" (1393), "by the gods" (1402), "Zeus" (1405), "calling the daimons to witness" (1410).

This is the final image broken in the play, that of Jason as the rational, social animal. He still cannot understand the power of love, but Medea has forced him to yield to that power and to speak its language. This is the language of the tribe, of the family. Jason has learned, too late, to revere Aphrodite, the "savior of his voyage."

The Lysistrata follows a pattern which resembles that of the Medea. The violation of the female by the male in this case has been the continuation of the war. This has upset the orderly arrangement of society (e.g., the men in armor who

33. C. Whitman, Aristophanes and the Comic Hero (Cambridge, Mass., 1964), p. 205, points out that the play is not simply about sex, but about married sex. D. S. Parker, in the introduction to his translation of "Lysistrata" in W. Arrowsmith (ed.), Aristophanes: Four Comedies (Ann Arbor, 1969), p. 2, goes beyond this and speaks of the wider role of the oikos in the play.

34. Whitman denies (op. cit., p. 202) that Lysistrata is masculine because she has strength of mind: $\because .$. whoever considers that quality a strictly masculine one is in error, not to say danger." This is true enough: there is nothing masculine about Lysistrata's nature; it is her field of action that is masculine. She operates in a social context, organizing the women, arguing with the men (she carefully explains why she can argue in 1125-27). When Parker (op. cit., p. 4) calls Lysistrata a "grande dame," he is describing her mixture of femininity and social skills. appear in the agora, 557-58), but, more specifically, it is a crime against the oikos and the women who live there. ${ }^{33}$ This crime is described in comic terms at the play's beginning when Lysistrata complains, and her friends agree, that the women are being denied sex (99-110); Lysistrata raises the same idea, this time in pathetic terms, to the proboulos (594 97), when she describes the young girls whose youth is passing without hope of marriage because war has emptied Athens of men.

The women who set the plot in motion, Lysistrata and Lampito, both have male characteristics: Lysistrata can plan "social action," and the physically robust Spartan provides the decisive impulse to act. ${ }^{34}$ Although the female takes on male characteristics in order to act in the world of society, she does not become male.35 Her action itself is typically female.

In this Lysistrata differs from Medea. Medea accepts male values, and tries to destroy her enemies; Lysistrata wants to force the male to submit to oikos values. Thus Medea's feminine actions are aimed at a male goal, domination over her enemies and fame; Lysistrata's feminine actions, directed by male qualities, are aimed at a feminine goal, harmony.

That Lysistrata's actions are feminine in nature is vividly presented in her scene with the proboulos, the scene where male meets

35. I would for the most part agree with Whitman when he says (op. cit., p. 202) that Lysistrata is "a woman, with a woman's purpose and a woman's methods [over 'methods' I would disagree], and when her purpose is accomplished, she retires with becoming modesty, presumably into the arms of her own husband." If the female intruder succeeds, whe usually does return to the house. We could say the same eren of Clytemnestra (except that the husband into whose armas: she retires is not the husband she left). Medea is the only woman in extant Greek tragedy who actually becomes a man when she takes on masculine characteristics; and, as we have seen, even in Medea the conversion is never quite completed. The confusion between woman as a state of nature and woman as a social role has distorted Whitman's argument here, I believe, as it distorts much of the discussion about the place of women. 
female. ${ }^{36}$ After the proboulos has tried to assert his authority and failed, ${ }^{37}$ the sexes are formally reversed: the proboulos is given women's clothes and the wool basket and is forced to listen (530-38). Lysistrata then speaks on a male topic (how to run the state) from a woman's point of view (the famous wool-working paradigm) ${ }^{38} \mathrm{Her}$ speech stresses, not competition, but co-operation and equality-i.e., the principles of oikos management.

The following scenes demonstrate the power of sex. First, we see the women's war with themselves, as they try to escape from the Acropolis (706-80). This is climaxed by the Cinesias-Myrrhine scene (829-979), the victory of female over male.

When the Spartan herald arrives (980), the battle is over; the male image is shattered. Both Spartans and Athenians have none of the male, social concerns now; instead, they are obsessed with, and governed by, the power of Aphrodite. This new orientation of the male is what lies behind the "negotiations" (1111-88). Spartans and Athenians gaily trade military strongpoints with sexually convenient names because their eyes are fixed on Reconciliation's body (1157-58). The point is simple enough: once Spartan and Athenian have admitted what each of them, like all men, wants above all, the process of negotiation will work, and only then. Croiset puts this

36. Lys. 387-613. There are some obvious parallels between this scene and the first meeting of Jason and Medea. The male is nominally dominant, but we already suspect this dominance. There is no action, because the point of the scene is to show the male-female impasse, and to develop the female's case, the male's ineffectualness. The arguments put by the two heroines are similar: Medea appeals to the sanctity of oaths (Medea 492-95), and Lysistrata adapts wool-working techniques to politics (Lys. 574-86); that is, both declare oikos values which have been betrayed.

37. The proboulos confirms in his first speeches the basic theme of the play, that males have betrayed the oikos. First (387-98), he says that he recognizes this female outbreak as an attack of orgiastic religion (387-89), because he heard it once before, while the assembly was deciding to send the expedition to Sicily. The connection of female folly with male folly is a revealing slip, a wry joke which invites the spectator to consider who was the crazier. But there is something more somber to,consider, forced on us by what we have seen in the neatly when he says of Aristophanes' purpose in the Lysistrata: "It is the moral preparation for peace, the appeal to sentiments which are to make it possible, that interests him, and that he regards as his task." 39

This new formulation of male and female is given symbolic fulfillment in the Spartan's two songs which close the play (1247-70, 1296-1320). First he sings of the martial courage which Athens and Sparta displayed together defending their homes against the Mede; then he sings of girls dancing to Athena of the Brazen House. The men defend the oikos; the women play their dignified and gracious role in a society that is not harmful to their interests. This, and this alone, is a condition of cultural health in the Greek polis.

This brief treatment has demonstrated, I hope, a pattern in the use of the image of male and female which is widely prevalent in fifth-century Athenian literature. Perhaps we could call this pattern the "intrusive female." Its general outline is roughly the following: (1) a man, acting as pure male, does something which threatens the pure female; (2) the pure female comes out of the oikos and opposes the male; (3) there is an impasse; (4) the female, taking some male attributes, acts; (5) a previously invisible feminine aspect of the male (e.g., his love for his children)

play: the connection is causal. Then, the proboulos explains that the men are at fault (403-42) because they invite craftsmen into the home and the women are corrupted. These are merely jokes, but their theme is an interesting one, the reverse of the intrusive female, the intrusive male. The proboulos knows what is wrong, the oikos is contaminated. But he refuses to see why it is contaminated.

38. Lys. 567-70, 574-87. When K. J. Dover, Aristophanic Comedy (Berkeley, 1972), p. 161, calls this speech "a recipe... for strength" and concludes that "from a position of strength one can get a peace which is to one's own advantage," he misses the essential link between Lysistrata's two speeches. In both domestic and international policies Athens suffers from a disordering of priorities. In both spheres, competition for honor has displaced an overriding concern with civic harmony, and domestic divisiveness feeds the unquenchable competitiveness in international affairs.

39. M. Croiset, Aristophanes and the Political Parties at Athens, trans. J. Loeb (London, 1909), p. 141. 
is destroyed; (6) there is a new formation, with male and female no longer pure.

Something closely resembling this pattern appears in works of Attic literature other than those we have considered, e.g., in the Oresteia, Antigone, Trachiniai, and Alcestis. Why should this be so?

Perhaps the answer can be found in the plays we have considered. In each of these plays, the male represents certain qualities, and the female counters, protecting certain qualities. Ajax declares that you must harm your enemies; Tecmessa counters that you must help your friends. Jason declares that all means are subordinate to profit; Medea answers that you must harm your enemies and help your friends. The Athenians are obsessed with competition; Lysistrata comes out to defend co-operation.

In each case the man has decided that certain values are paramount, because of reasoning that is fundamentally societyoriented, while the woman represents complementary values, which society has slighted. This explains, I think, why we are prompted to say that Medea is, and always has been, a better man than Jason. In the Ajax, since Ajax represents hate and Tecmessa represents love, the conflict between them, strong as it is, is not absolute, since they are both human in the same sense. Jason, however, has excluded emotion altogether, and thus Medea represents both hate and love.

It serves the highest good of society for the members of society to be fully human, but the very operation of society erodes the character of its members. The first necessity of society is that it be autonomous; to gain this autonomy, society's members must put hatred above love, in order that enemies may be repelled. In the courts, the market, and the assembly, a man is taught to keep a hard eye on his interests and to be wary of appeals to his emotions.
To the artist is given the job of restoring the balance, to insure that the necessities of power do not make its holders mere creatures of power, such as Agamemnon in the Ajax or the Athenians in the Melian Dialogue. And in this essential task, it seems clear, the artists found the Greek women to be necessary allies. The oikos, carefully kept separate from society, was a reservation, a protected area, where the educative influence of society did not reach. The women, carefully secluded from the effects of citizenship and power, cultivated in seclusion those virtues which were always threatened in the state itself.

By dramatizing the points of conflict between the oikos and the state, the artist could chart the limits and shortcomings of the civic virtues. By showing the opposition of oikos and state, the artist illustrates the need for that harmony between Realpolitik and concern for the weak, between practicality and poetry, between discipline and freedom, which was always the Athenian ideal, the harmony we find so eloquently described in the Funeral Oration of Pericles.

Perhaps our conclusions about the function of women will help explain the notorious absence of women from this famous speech. The ideal Athens which Pericles pictures does in fact harmonize eros and sophia. Men compete in doing good for the state, but the destructive aspect of competition, envy (phthonos), is absent. The weaker are protected by the unwritten laws, and men practice "refinement without extravagance and knowledge without effeminacy" (Thuc. 2. 40, in Crawley's translation). The true Greek ideal, harmony of male and female, is achieved. There is no need for the woman to intrude into this society, because it has not betrayed her.

\section{UNIVERSTTY OF KANSAS}

